\title{
PENGARUH PERSEPSI SISWA TENTANG PENGELOLAAN KELAS DAN MOTIVASI BELAJAR TERHADAP PRESTASI BELAJAR EKONOMI SISWA KELAS XI JURUSAN AKUNTANSI SMK NEGERI 1 MEDAN T.A 2017/2018
}

\author{
Ayu Fitrida Purba, Dearlina Sinaga, Sopar Simatupang \\ Program Studi Pendidikan Ekonomi, Fakultas Keguruan dan Ilmu Pendidikan \\ Universitas HKBP Nommensen Medan \\ Correspondent Email: Ayupurba1995@gmail.com
}

\begin{abstract}
Abstrak
Penelitian ini bertujuan untuk mengetahui: (1) pengaruh persepsi siswa tentang pengelolaan kelas terhadap prestasi belajar ekonomi siswa kelas XI SMKNegeri 1 Medan tahun ajaran 2017/2018, (2) pengaruh motivasi belajar terhadap prestasi belajar ekonomi siswa kelas XI SMK Negeri 1 Medan tahun ajaran 2017/2018, (3) pengaruh persepsi siswa tentang pengelolaan kelas dan motivasi belajar terhadap prestasi belajar ekonomi siswa kelas XI SMK Negeri 1 Medan tahun ajaran 2016/2017. Penelitian ini merupakan penelitian dengan pendekatan kuantitatif. Populasi penelitian ini adalah siswa kelas XI SMK Negeri 1 Medan sejumlah 149. Sebanyak 10 siswa digunakan untuk pengujian validitas angket, sedangkan 36 responden sebagai data penelitian. Teknik pengumpulan data menggunakan angket dengan model skala likert 4 alternatif jawaban. Analisis data yang digunakan adalah regresi linear berganda. Hasil penelitian menunjukkan: (1) terdapat pengaruh positif persepsi siswa tentang pengelolaan kelas terhadap prestasi belajar ekonomi siswa kelas XI SMK Negeri 1 Medan tahun ajaran 2017/2018; sebesar 3,628 (2) terdapat pengaruh positif motivasi belajar terhadap prestasi belajar ekonomi siswa kelas XI SMK Negeri 1 Medan tahun ajaran 2017/2018; 2,371 (3) terdapat pengaruh positif persepsi siswa tentang pengelolaan kelas dan motivasi belajar secara bersama-sama terhadap prestasi belajar ekonomi siswa kelas XI SMK Negeri 1 Medan tahun ajaran 2017/2018 dan sebesar 42,3\%.
\end{abstract}

\section{Kata Kunci : Persepsi Siswa Tentang Pengelolaan Kelas, Motivasi Belajar, Prestasi Belajar}

\begin{abstract}
This study aims to determine: (1) the influence of students' perceptions about classroom management on the economic achievement of students of class XI SMKNegeri 1 Medan academic year 2017/2018, (2) the influence of learning motivation toward the economic achievement of students of class XI SMK Negeri 1 Medan academic year 2017/2018, (3) the influence of students' perceptions about classroom management and learning motivation on the economic achievement of students of class XI SMK Negeri 1 Medan academic year 2016/2017. This research is a research with quantitative approach. The population of this study is the students of grade XI SMK Negeri 1 Medan number 149. A total of 10 students are used to test the validity of the questionnaire, while 36 respondents as research data. Technique of collecting data using questionnaire with Likert scale 4 alternative answer model. The data analysis used is multiple linear regression. The results showed: (1) there is a positive influence of students 'perceptions about classroom management on students' economic achievement class XI SMK Negeri 1 Medan academic year 2017/2018; amounted to 3,628
\end{abstract}

\footnotetext{
JURNAL WIDYA This work is licensed under a Creative Commons Attribution-NonCommercialShareAlike 4.0 International License.
} 
(2) there is a positive influence of learning motivation on economic achievement of students of class XI SMK Negeri 1 Medan academic year 2017/2018; 2.371 (3) there is a positive influence of students' perception about classroom management and learning motivation together on the economic learning achievement of students of class XI SMK Negeri 1 Medan academic year 2017/2018 and by $42.3 \%$.

\section{Key Words : Student Perception About Classroom Management, Learning Motivation, Student Achievement.}

\section{PENDAHULUAN}

Pendidikan tidak terlepas dari keseluruhan kegiatan manusia baik dalam keluarga, sekolah dan ditengah masyarakat. Pendidikan adalah usaha sadar dalam terencana untuk mewujudkan suasana belajar dan proses pembelajaran agar peserta didik secara aktif mengembangkan potensi dirinya untuk memiliki kekuatan spiritual keagamaan, pengendalian diri, kepribadian, kecerdasan ahklak mulia serta keterampilan yang diperlukan dirinya, masyarakat, bangsa dan negara. Melalui pendidikan seseorang dapat mencapai kesuksesannya karena didalam pendidikan telah diajarkan mengenai pengetahuan, keterampilan dan sikap hal inilah merupakan cara peningkatan kualitas sumber daya manusia. Pada masa era globalisasi ini persaingan semakin ketat dan perkembangan jaman semakin cepat. Ini menyebabkan kebutuhan masyarakat dalam berbagai bidangpun semakin banyak dan beragam. Dengan pendidikan diharapkan dapat menciptakan manusia yang produktif yang mampu memajukan bangsanya.

Ekonomi merupakan mata pelajaran yang cukup berperan penting dalam penambahan pengetahuan seorang siswa karena ekonomi adalah ilmu tentang perilaku dan tindakan manusia untuk memenuhi kebutuhan hidupnya yang bervariasi dan berkembang dengan sumber daya yang ada melalui pilihan-pilihan kegiatan produksi, konsumsi dan atau distribusi. Dalam dunia pekerjaan pun pengetahuan tentang ekonomi sangat dibutuhkan karena didalam setiap bidang pekerjaan, ekonomi selalu melekat dalam setiap bidang pekerjaan yang akan berhubungan dengan perilaku dan tindakan manusia dalam pemenuhan kebutuhannya. Berdasarkan hal diatas siswa diharapkan memiliki motivasi untuk memahami pelajaran ekonomi.

Dari observasi di lapangan, penulis menemukan kurangnya motivasi siswa dalam menerima pembelajaran, hal ini terlihat dari adanya siswa yang telat masuk kelas, tidak mengerjakan tugas dan berbicara dengan temannya saat guru menerangkan pelajaran. Namun guru memberikan arahan kepada siswa untuk mengikuti proses pembelajaran dengan baik seperti guru memberikan kebebasan pada siswa untuk memberikan pendapatnya tentang pelajaran, akan tetapi tetap saja terlihat kurangnya motivasi belajar pada siswa, terbukti dari rata-rata nilai ekonomi siswa pada kelas XI masih rendah yaitu 65. Padahal kalau mengingat bahwa pelajaran ekonomi sangat penting bagi siswa kejuruan dimana siswa tersebut memilih sendiri jurusan yang diinginkannya, seharusnya hal tersebut tidak terjadi tetapi begitulah keadaan dilapangan bahwa prestasi belajar siswa yang didapat memang rendah dan perlu ditingkatkan.

Dari pembahasan yang dikemukakan diatas, maka penulis tertarik untuk mengadakan penelitian dengan judul "Pengaruh Persepsi Siswa tentang Pengolahan Kelas dan Motivasi Belajar terhadap Prestasi Belajar Ekonomi Siswa Kelas XI di SMK N 1 Medan T.P 2016/2017”.

\section{METODOLOGI PENELITIAN}

Metode Penelitian ini menggunakan metode penelitian Kualitatif dan kuantitatif yaitu dengan teknik pengupulan data kelapangan dan membagikan kusioner. Untuk memperoleh data yang akurat dalam penelitian ini, maka yang menjadi teknik pengumpulan data yang dilakukan oleh penelitian dengan cara:

\section{a) Dokumentasi}


Untuk memperoleh data sekunder objek penelitian dalam hasil belajar dimana data tersebut diperoleh dari arsip - arsip SMK N 1 Medan berupa daftar kumpulan nilai (DKN).

\section{b) Kuesioner / Angket}

Angket digunakan untuk memperoleh data variable X1 (Persepsi siswa terhadap pengelolaan kelas) dan X2 (Motivasi belajar) yaitu dengan meyebar angket kepada sampel penelitian. Jumlah soal yang tertera pada angket adalah sebanyak 20 soal untuk variabel Persepsi siswa terhadap pengelolaan kelas dan Motivasi belajar 20 soal untuk yang masing-masing disertai dengan pilihan berganda sebanyak 4 option(pilihan) yang masing-masing diberi pilihan

\section{HASIL DAN PEMBAHASAN}

A. Teknik Analisis Data

1. Uji Regresi Linear Berganda

Hasil analisi regresi diperoleh koefisien untuk XI $=0,560$ nilai ini dapat dilihat pada kolom B pada baris Persepsi siswa tentang pengelolaan kelas, $\mathrm{X} 2=0,389$ dilihat pada kolom B pada baris Motivasi belajar dan konstanta sebesar 67,143 dilihat pada kolom B pada baris konstan. Sehingga model persamaan regresi yang diperoleh adalah sebagai berikut: $\mathrm{Y}=67,143+0,560_{\mathrm{X} 1}+0,389_{\mathrm{X} 2}$

Tabel 4.10

\section{Coefficients $^{\mathbf{a}}$}

\begin{tabular}{|c|c|c|c|c|c|c|}
\hline \multirow{2}{*}{\multicolumn{2}{|c|}{ Model }} & \multicolumn{2}{|c|}{$\begin{array}{l}\text { Unstandardized } \\
\text { Coefficients }\end{array}$} & $\begin{array}{l}\text { Standardize } \\
\mathrm{d} \\
\text { Coefficient } \\
\mathrm{s}\end{array}$ & \multirow[t]{2}{*}{$\mathrm{T}$} & \multirow[t]{2}{*}{ Sig. } \\
\hline & & B & Std. Error & $\begin{array}{c}\text { Bet } \\
\mathrm{a}\end{array}$ & & \\
\hline \multirow[t]{3}{*}{1} & (Constant) & 67,143 & 17,796 & & 3,773 &, 000 \\
\hline & $\begin{array}{l}\text { Persepsi siswa } \\
\text { tentang } \\
\text { pengelolaan kelas }\end{array}$ &, 560 & , 193 & ,343 & 3,628 & ,001 \\
\hline & Motivasi belajar & ,389 & ,139 & ,264 & 2,371 & ,001 \\
\hline
\end{tabular}

a. Dependent Variable: Prestasi belajar

\section{Sumber : Pengolahan data dengan menggunakn program}

\section{Uji Normalitas}

Metode paling handal adalah melihat normal probability plot yang membandingkan distribusi kumulatif dan distribusi normal. Distribusi normal akan membentuk satu garis lurus diagonal. Jika distribusi normal, maka garis yang menggambarkan data yang sesungguhnya akan menjadi garis diagonalnya.

\section{Gambar 4.1}




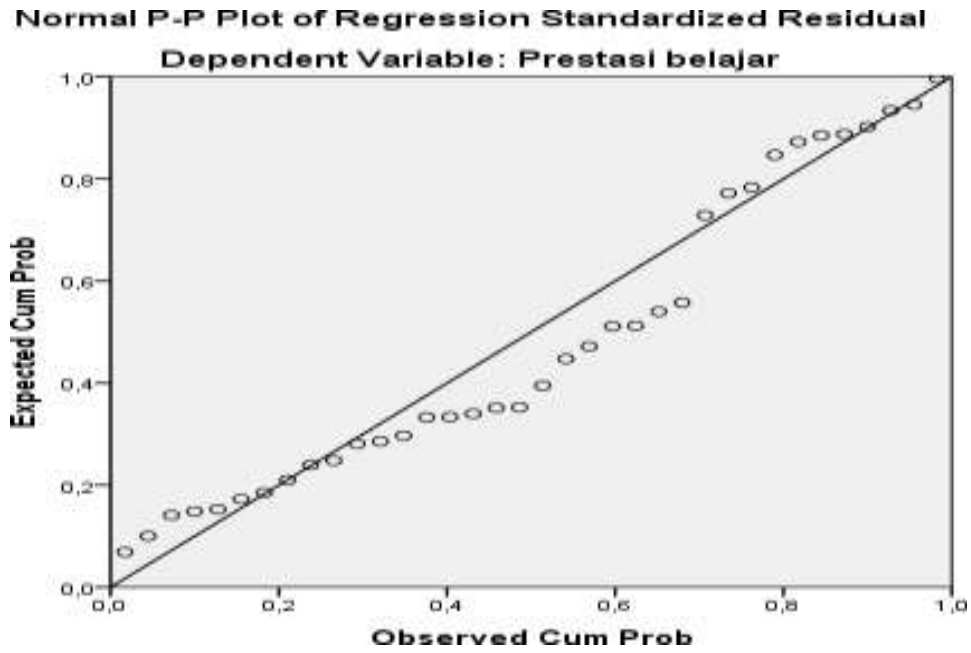

\section{Pengujian Hipotesis Secara Parsial (Uji t)}

Untuk menguji hipotesis yang menyatakan variabel Persepsi siswa tentang pengelolaan kelas XI dan Motivasi belajar X2 secara parsial mempengaruhi Prestasi belajar ekonomi siswa, maka digunakan uji-t, pengujian hipotesis dilakukan dengan membandingkan besarnya taraf signifikan penelitian dengan taraf $95 \%$ atau $\alpha<0,05$ dan hasil $t_{\text {hitung }}$ dapat dilihat pada tabel 4.11:

Tabel. $\quad 4.11$

\section{Uji Hipotesis (Uji-t)}

Coefficients $^{\mathbf{a}}$

\begin{tabular}{|c|c|c|c|c|c|c|}
\hline \multirow{2}{*}{\multicolumn{2}{|c|}{ Model }} & \multicolumn{2}{|c|}{$\begin{array}{l}\text { Unstandardi } \\
\text { zed } \\
\text { Coefficients }\end{array}$} & \multirow{2}{*}{$\begin{array}{l}\text { Standardize } \\
\mathrm{d} \\
\text { Coefficient } \\
\mathrm{s} \\
\begin{array}{c}\text { Bet } \\
\mathrm{a}\end{array}\end{array}$} & \multirow[t]{2}{*}{$\mathrm{T}$} & \multirow[t]{2}{*}{ Sig. } \\
\hline & & B & Std. Error & & & \\
\hline & (Constant) & 67,143 & 17,796 & & 3,773 & 000 \\
\hline & $\begin{array}{l}\text { Persepsi siswa } \\
\text { tentang } \\
\text { pengelolaan kelas }\end{array}$ & 635 & , 193 & ,343 & 3,628 & ,001 \\
\hline & Motivasi belajar & 295 & ,139 & ,264 & 2,371 & ,001 \\
\hline
\end{tabular}

a. Dependent Variable: Prestasi belajar

Sumber : Pengelolaan data dengan menggunakan program SPSS 22

\section{Pengujian Hipotesis Secara Simultan (Uji F)}

Untuk mengetahui pengaruh kedua variabel bebas secara bersama-sama terhadap variabel terikat digunakan Uji F. Berdasarkan hasil pengolahan dengan program SPSS. 22 for windows dapat dilihat pada tabel 4.12 sebagai berikut:

Tabel. $\quad 4.12$ 


\section{Uji Simultan (Uji-F)}

ANOVA $^{\mathrm{a}}$

\begin{tabular}{|c|c|c|c|c|c|}
\hline Model & $\begin{array}{l}\text { Sum of } \\
\text { Squares }\end{array}$ & $\begin{array}{l}D \\
f\end{array}$ & $\begin{array}{r}\text { Mean } \\
\text { Square }\end{array}$ & $\mathrm{F}$ & Sig. \\
\hline \begin{tabular}{|ll}
1 & Regression \\
& Residual \\
& Total
\end{tabular} & $\begin{array}{r}429,872 \\
272,878 \\
1302,750\end{array}$ & $\begin{array}{r}2 \\
34 \\
36\end{array}$ & $\begin{array}{r}214,936 \\
38,572\end{array}$ & $\begin{array}{l}11,38 \\
7\end{array}$ &, 000 \\
\hline
\end{tabular}

a. Dependent Variable: Prestasi belajar

b. Predictors: (Constant), Motivasi belajar, Persepsi siswa tentang pengelolaan kelas

\section{Sumber: Pengolahan data dengan menggunakan program SPSS 22}

\section{Koefisien Determinasi $\left(\mathbf{R}^{2}\right)$}

Koefisien determinasi digunakan untuk melihat besarnya kontribusi variabelvariabel independent/bebas Persepsi siswa tentang pengelolaan kelas $\left(\mathrm{X}_{1}\right)$ dan Motivasi Belajar $\left(\mathrm{X}_{2}\right)$, terhadap variabel dependen yaitu prestasi belajar ekonomi siswa kelas XI jurusan Akuntansi SMK N 1 Medan. Perhitungan koefisien determinasi dapat dilihat pada tabel 4.13:

\section{Tabel 4.13}

\section{Tabel Koefisien Determinasi $\left(\mathbf{R}^{2}\right)$}

\section{Model Summary}

\begin{tabular}{|l|r|r|r|c|}
\hline Model & $\mathrm{R}$ & $\mathrm{R}$ Square & $\begin{array}{c}\text { Adjusted } \\
\mathrm{R} \\
\text { Square }\end{array}$ & \multicolumn{1}{c|}{$\begin{array}{c}\text { Std. Error of } \\
\text { the } \\
\text { Estimate }\end{array}$} \\
\hline 1 & $\substack{\mathrm{a} \\
\mathrm{a}}$ &, 423 &, 236 & 6,21153 \\
\hline
\end{tabular}

a. Predictors: (Constant), Motivasi belajar, Persepsi siswa tentang pengelolaan kelas

\section{B. Pembahasan}

\section{Pengaruh Persepsi Siswa Tentang Pengelolaan Kelas}

Berdasarkan hasil penelitian menunjukkan bahwa nilai rata-rata angket persepsi siswa tentang pengelolaan kelas sebesar 3,21 tergolong Setuju kemudian terdapat keeratab hubungan yang timggi antara Persepsi siswa tentang pengelolaan kelas dengan Prestasi belajar. Uji normalitas digunakan oleh peneliti karena jumlah sampel yang di mabil adalah 36 orang, dan dari hasil uji normalitas 
tersebut terlihat bahwa hasilnya berdistribusi normal. Berdasarkan hasil pengujian hipotesis $\mathrm{t}_{\text {hitung }}>$ $\mathrm{t}_{\text {hitung }}$ atau 3,628 > 0329. Dimana taraf signifikan 95\% atau alpha 5\%. Hal ini menunjukkan bahwa hipotesis yang menyatakan "Ada pengaruh yang positif dan signifikan antara Persepsi siswa tentang pengelolaan kelas terhadap Prestasi belajar siswa pada mata pelajaran ekonomi kelas XI jurusan akuntansi SMK N 1 medan tahun ajaran 2017/2018 diterima.

\section{Pengaruh Motivasi Belajar Terhadap Prestasi Belajar}

Berdasarkan hasil penelitian menunjukkan bahwa nilai rata-rata angket kecerdaan emosional sebesar 3,45 tergolong Sangat Setuju. Uji normalitas digunakan oleh peneliti karena jumlah sampel yang diambil adalah 36 orang, dan dari hasil uji normalitas tersebut terlihat bahwa hasilnya berdistribusi normal. Berdasarkan hasil pengujian hipotesis $t_{\text {hitung }}>t_{\text {tabel }}$ atau 2,371 $>0,329$. Dimana taraf signifikan 95\% atau alpha 5\%. Hal ini menunjukkan bahwa hipotesis yang menyatakan "Ada pengaruh yang positif dan signifikan antara Motivasi belajar dengan Prestasi belajar pada mata pelajaran ekonomi kelas XI jurusan akuntansi SMK N 1 Medan tahun ajaran 2017/2018 diterima.

\section{Pengaruh Persepsi Siswa Tentang Pengelolaan Kelas Terhadap Prestasi Belajar Dan Motivasi Belajar Ekonomi Siswa kelas XI SMK N 1 Medan T.A 2017/2018}

Berdasarkan hasil penelitian menunjukkan bahwa secara keseluruhan hasil belajar tergolong rata-rata baik. Dimana siswa yang memperoleh prestasi belajar kategori sangat baik terdapat 10 orang reponden (28\%), kategori baik terdapat 26 responden (72\%). Prestasi siswa tersebut dapat dilihat dari besarnya persepsi siwa tentang pengelolaan kelas, adapun pergertian persepsi siswa tentang pengelolaan kelas berkenaan dengan tujuan yang ditetapkan dapat dicapaisesuai harapan. Ini terlihat dari cara guru dalam mengelola kelas dengan baik akan membuat siswa aktif dalam pelajaran. Dan motivasi siswa dalam belajar juga tergolong baik sehingga dapat membantu Pmeningkatkan prestasi belajar. Hal ini menunjukkan bahwa hipotesis yang menyatakan ada hubungan yang positif dan signifikan secara bersama-sama antara persepsi siswa tentang pengelolaan kelas dan motivasi belajar terhadap prestasi belajar kelas XI SMK N 1 Medan Tahun Ajaran 2017/2018 diterima.

\section{KESIMPULAN}

Berdasarkan hasil analisis data dan pembahasan yang telah diuraikan pada bab sebelumnya mengenai pengaruh persepsi siswa tentang pengelolaan kelas dan motivasi belajar terhdapa prestasi belajar ekonomi siswa, maka dapat diambil kesimpulan sebagai berikut:

1. Terdapat pengaruh positif dan signifikan antara persepsi siswa tentang pengelolaan kelas terhadap prestasi belajar ekonomi siswa kelas XI jurusan akuntansi tahun ajaran 2017/2018. Hal ini dibuktikan dengan $\mathrm{N}=36$ nilai koefisien variabel siswa tentang pengelolaan kelas sebesar 3,628 dengan taraf signifikan 0,01

2. Terdapat pengaruh positif dan signifikan antara motivasi belajar terhadap prestasi belajar ekonomi siswa kelas XI jurusan akuntansi tahun ajaran 2017/2018. Hal ini dibuktikan dengan $\mathrm{N}=36$ nilai koefisien variabel motivasi belajar sebesar 2,371 dengan taraf signifikan 0,01 .

3. Terdapat pengaruh positif dan signifikan antara persepsi siswa tentang pengelolaan kelas dan motivasi belajar siswa terhadap prestasi belajar ekonomi siswa kelas XI jurusan akuntansi tahun ajaran 2017/2018. Persamaan regresi yang dihasilkan dalam penelitian $\mathrm{Y}=3,628 \mathrm{X}_{1}+$ $2,371 \mathrm{X}_{2}+3,773$.

Variabel prestasi belajar siswa dalam penelitian ini dipengaruhi oleh variabel persepsi siswa tentang pengelolaan kelas dan motivasi belajar siswa sebesar $42,3 \%$. Sedangkan sisanya 57,7\% variabel prestasi belajar siswa dapat di jelaskan oleh variabel lain 
yang tidak diteliti oleh peneliti.

\section{DAFTAR PUSTAKA}

[1] A.M Sardiman. 2011. Interaksi dan Motivasi Belajar Mengajar. Jakarta: Rajawali Pers. Arikunto

[2] Suharsimin. 2009. Dasar-dasar Evaluasi Pendidikan. Jakarta: Bumi Aksara. 2014. Prosedur Penelitian Suatu Pendekatan Pakrik. Jakarta: Rineka Cipta.

[3] Djamarah Bahri, Zain. 2010. Strategi Belajar Mengajar. Jakarta: Rineka Cipta

[4] Fuad, Chiristine dkk. 2001. Pengantar Bisnis. Jakarta: PT Gramedia Pustaka Utama. Hamdani. 2017. Strategi Belajar Mengajar. Bandung: Pustaka Setia Bandung.

[5] Slameto. 2010. Belajar dan Fakror-faktor Yang Mempengaruhi. Jakarta: Rineka Cipta.

[6] Sudjana, Nana. 2016. Penilaian Hasil Proses Belajar Mengajar. Bandung: PT Remaja Rosdakarya.

[7] Sugiyono. 2014. Metode Penelitian Pendidikan Pendekatan Kuantitatif Kualitatif dan R\&D. Bandung: Alfabeta.

[8] Uno B Hamzah. 2011. Teori Motivasi dan Pengukurannya Analisis di Bidang Pendidikan. Jakarta: Bumi Aksara.

[9] Walgito Bimo. 2010. Pengatar Psikologi Umum. Yogyakarta: Andi Offset.

[10] Andyarto Sudjana. 2004. Efektivitas Pengelolaan Kelas "BPK PENABUR" di Jakarta. Jurnal Pendidikan Penabur- No.02/Th.111/Maret2004. (http://www.geocities.ws/dien_sib24gd/fei/068-081.pdf) (diakses 3 Mei 2017)

[11] Linda Setiawan., Jurnal (2015), Faktor-faktor Yang Mempengaruhi Belajar Praktik Kejujuran Siswa SMK Program Studi Keahlian Teknik Komputer Dan Informatika, (http://journal.uny.ac.id/index.php/jpv/article/download/6487/5585) (diakses 20 Mei 2017) 